\title{
PARVOVIRUSAS B19: STRUKTŪRA, PATOGENEZĖ, EPIDEMIOLOGIJA, ORGANIZMO IMUNINIS ATSAKAS
}

\author{
Milda Naciūtė, Diana Mieliauskaitė, Irutė Girkontaitė \\ Valstybinis moksliniu tyrimu institutas Inovatyvios medicinos centras
}

Raktažodžiai: parvovirusas B19, imuninis atsakas, patogenezè, infekcija, epidemiologija.

\begin{abstract}
Santrauka
Parvovirusas B19 yra vienas mažiausių žinomų DNR genomą turinčių virusų, kurie gali infekuoti žinduolių ląsteles. Šis virusas paplitęs visame pasaulyje. Jis plinta lašeliniu būdu bei per donoru kraują. Parvoviruso B19 infekcija dažniausiai persergama vaikysteje ir daugelis suaugusiujų jau turi IgG antikūnus prieš parvovirusą B19.

Parvoviruso B19 infekcija sukelia neženklius pažeidimus, neretai infekcijos metu nèra jokios klinikinès raiškos. Vaikams parvovirusas B19 sukelia infekcinę eritemą, o suaugusiems gali sukelti artralgijas ir artropatijas. Parvovirusas pavojingas asmenims, kuriems yra imuniniai ir hematologiniai sutrikimai, dèl parvoviruso B19 jiems gali atsirasti sunki anemija. Taip pat virusas pavojingas néščioms moterims, nes sukelia vaisiaus pažeidimus, vaisiaus vandenligę, netgi persileidimus. Parvoviruso B19 infekcija dažniau būna sergant tam tikromis ligomis (reumatoidiniu artritu, raudonaja vilklige, esant lètinio nuovargio sindromui, kardiopatijai). Kaip virusas veikia šių ligų patogenezèje iki šiol nėra žinoma. Šiame straipsnyje apibendrinami naujausi mokslinès literatūros duomenys apie parvoviruso B19 struktūrą, patogenezę, epidemiologiją, organizmo imuninị atsaką bei infekcijos nustatymo metodus.
\end{abstract}

\section{Ivadas}

Parvovirusai - vieni mažiausių DNR genomą turinčių virusų. Virusų šeimos Parvoviridae pavadinimas kilęs iš lotyniško žodžio „parvum“, reiškiančio „mažas“ $[1,2]$. Parvovirusai gyvūnų pasaulyje plačiai paplitę, jie infekuoja stuburinius, vabzdžius ir vėžiagyvius. Mokslo bendruomenè daugiausia dèmesio skiria patologiniams žinduolių parvovirusams: šunis, kates, kiaules ir ypač žmones infekuojantiems parvovirusams. Žinomi 4 žmones infekuojan- tys parvovirusai: dependovirusai, žmogaus bokavirusai, parvovirusas B19 ir PARV4 [3].

Žmogaus parvovirusą B19 pirmoji aprašè australè virusologè Yvonne Cossart, dirbusi Londono laboratorijoje,1975 metais. Tirdama sveikų donorų kraujo serumą viename iš mèginių (B plokštelèje, 19 pozicijoje) pastebèjo neiprastą reakciją. Tuomet mokslininkè atliko hemagliutinacijos ir radioimuninius tyrimus hepatito $\mathrm{B}$ nustatymui, kurie buvo neigiami ir, galiausiai, elektroninès mikroskopijos nuotraukose išvydo virusų daleles, primenančias gyvūnų parvovirusus [4]. Po 5 metų Japonijoje aptiktas Nakatani (,serumo dalelè, panaši i parvovirusą“) arba kitaip žmogaus parvovirusas, kuris pasirode esantis tas pats Cossart aptiktas parvovirusas. Praejjus dešimtmečiui nuo viruso atradimo, $1985 \mathrm{~m}$. Virusų taksonomijos tarptautinis komitetas (International Committee on Taxonomy of Viruses) priskyre šị virusą Parvoviridae šeimai ir suteikè oficialu pavadinimą - parvovirusas B19 [5].

Tiriant parvovirusą B19 aptiktos sąsajos su ịvairiomis ligomis. $1981 \mathrm{~m}$. pastebèta, kad infekuotiems ligoniams, sergantiems pjautuvine anemija, dažniau išsivysto aplastinè krizè, o 1983 m. nustatyta, kad šis virusas vaikams sukelia infekcinę eritemą. Neilgai trukus buvo aprašyti tokie simptomai, kaip vaisiaus praradimas per pirmus du néštumo trimestrus $[6,7]$. Vèliau aptiktas parvoviruso ryšys su ivvairiomis autoimuninemis ligomis. Nustačius, kad virusas gali būti perduodamas per donorų kraują, nuo 2002 m. Europoje rizikos grupėms perpilamas donorų kraujas tiriamas dẻl B19 ir stengiamasi užtikrinti viruso pašalinimą $[8,9]$.

$1986 \mathrm{~m}$. buvo nustatyta parvoviruso B19 genomo organizacija: atviro skaitymo rèmeliai, promotorius, pasikartojantys genomo galai bei struktūriniai ir nestruktūriniai baltymai [10]. Po keleto metu - 1989 m., nustatyta, kad parvovirusas infekuoja ir dauginasi pirmtakinèse eritroidinėse ląstelèse [11], o 1993 m. parodyta, kad B19 infekcijai reikalingas paviršiaus receptorius $-\mathrm{P}$ antigenas [12]. Pirmasis neutralizuojantis viruso antigenas (VP2 baltymo Ngalas - 328-344 a.r.) nustatytas $1991 \mathrm{~m}$. ir tai davé pradžią kitiems viruso patogenezès bei imuninio atsako tyrimams 
$[13,14]$. Nors iki šiu dienų sukaupta daug informacijos apie parvoviruso sukeliamas ligas, viruso patogenezę bei padaryta didelè pažanga kuriant vakciną prieš B19, tačiau dar daug klausimų yra neatsakytų.

Šio straipsnio tikslas - apibendrinti mokslinès literatūros duomenis apie parvoviruso B19 struktūrą, patogenezę, epidemiologiją, organizmo imunini atsaką bei infekcijos nustatymo metodus.

\section{Tyrimo medžiaga ir metodai}

Straipsnis parengtas pagal mokslinès literatūros sisteminès analizès rezultatus, kurie leidžia sisteminti ir vertinti sukauptus faktinius duomenis. Anglų kalba publikuotų mokslinès literatūros šaltinių paieška buvo vykdoma „PubMed“ duomenų bazejje. Paieškai anglų kalba naudoti šie raktažodžiai: ,parvovirus B19 “ and/or „cytokines“, „immune response“, „pathogenesis“, „structure“, ,diseases“, „detection methods“. Šioje apžvalgoje taip pat naudoti duomenys aprašyti knygose „A practical guide to clinical virology“, „Fields Virology“, „Desk encyclopedia of general virology“. Apžvelgti 1989-2013 m. moksliniai straipsniai.

\section{Rezultatai}

Parvoviruso B19 struktūra ir organizacija. Parvovirusai B19 yra vieni mažiausių virusų. Jų viriono dydis yra tik 22-24 nm. Viruso genomą sudaro 5596 nukleotidų ilgio viengrandinine DNR. Koduojančioje srityje yra du atviro skaitymo rèmeliai, kurie turi vieną promotorių. Vykstant transkripcijai sintetinami 9 transkriptai, kuriems būdingas alternatyvus splaisingas [5].

Virusas ekspresuoja 5 baltymus (1 pav.) - du iš jų yra struktūriniai baltymai VP1 ir VP2, vienas didysis nestruktūrinis baltymas NS1 bei du mažieji nestruktūriniai $11 \mathrm{kDa}$ ir 7,5 kDa baltymai [15].

Viruso kapside - ikosaedras, sudarytas iš 60 baltymų. Tai minimalus baltyminių subvienetu kiekis, reikalingas suformuoti ikosaedrinei viriono kapsidei. Viriono kapsidę sudaro du struktūriniai baltymai - VP1 ir VP2. Nustatyta, kad VP1 ir VP2 baltymai gali savaime susirinkti i kapsides, net ir nesant viruso DNR [5]. Didysis kapsidès baltymas VP2 apima 95 proc. kapsidès baltymų, o mažasis VP1

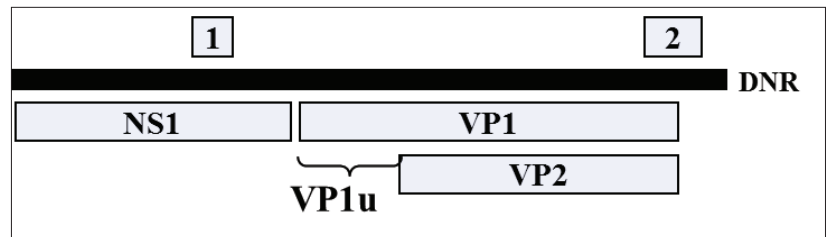

1 pav . Parvoviruso B19 struktūra

NSI (77kD), 1 (7,5kB);, 2 (11kb) - nestruktūrinai baltymai. VP1 (84kD ir VP2 (58kD) - struktūriniai baltymai
- 5 proc. [7]. Abu struktūriniai baltymai sudaro 80 proc. viriono masès [1]. Susirenkant kapsidei, paviršiuje atsiduria struktūrinių baltymų $\alpha$ kilpos, kurias imuninè sistema atpažista kaip antigenines determinantes. Viruso kapsidè labai stabili ir nèra lipidinio apvalkalèlio, dèl šių priežasčių virionai itin atsparūs aplinkos poveikiui. Virionas išlieka stabilus pH 3-9, $56^{\circ} \mathrm{C}$ temperatūroje, 60 min. Kadangi nèra lipidinio apvalkalèlio, virusas atsparus detergentams. B19 gali būti inaktyvuojamas formalinu, I2-propiolaktonu, hidroksilaminu ir oksiduojančiais agentais [3].

Kapsidès baltymai VP1 (2444-4786) ir VP2 (31254786) koduojami $5^{\prime}$ genomo. Abu genai koduojami tame pačiame skaitymo rèmelyje. VP1 (84 kDa) ir VP2 (58 kDa) yra identiški baltymai, tik VP1 baltymas turi papildomas 227 aminorūgštis N-galinèje baltymo dalyje. Splaisingo metu transkriptas gali būti kerpamas skirtingose srityse ir dèl to transliuojamas VP1 arba VP2 baltymas. VP1 baltymo $\mathrm{N}$-galas vadinamas unikaliu VP1 baltymo regionu (VP1u). Unikalus regionas išsikišęs ị viriono paviršiu, todèl imuninè sistema ji ,panaudoja“ kaip linijinių epitopų šaltini [8]. Šis regionas turi panašų i A2 fosfolipazès aktyvumą, kuris aktyvinamas paveikus žemomis $\mathrm{pH}$. Aktyvus domenas fosfolipidus skaido ị lizofosfolipidą (membraną lizuojanti detergentinè molekulè) ir arachidono rūgštị (uždegiminių signalų molekulè, tokia kaip leukotrienai ir prostaglandinai) [16]. Toks aktyvumas reikalingas infekcijos metu virusui išsilaisvinti iš endocitozinès vakuolès ir patekti ị ląstelès vidų. VP1u turi bazines aminorūgštis, kurios nukreipia viriono pernešimą ị branduolị. VP1 unikalus regionas reikalingas infektyvumui, bet ne kapsides formavimui ar DNR pakavimui [3].

Nestruktūrinis baltymas NS1 koduojamas 3' galinėje genomo puséje. Baltymas valdo viruso gyvenimo ciklą. NS1 baltymas yra daugiafunkcinis, nes turi keletą aktyvumų. Baltymo N-gale yra nukleotidų trifosfatų prisijungimo motyvas, šia dalimi baltymas jungiasi prie DNR. Centrinejje dalyje yra DNR kerpantis bei nuo ATP priklausomas helikazinis domenai, dalyvaujantys viruso replikacijos metu. C-galinè baltymo dalis yra P6 ir kitu ląstelinių promotoriu transaktyvatorius [15]. Aktyvuojami TNF $\alpha$, IL-6, NF-אB baltymų ir STAT signalinių kelių genų promotoriai, tai sukelia uždegimą ir pažeidimus. NS1 veikia transkripcijos reguliaciją tiesiogiai sąveikaudamas su Sp1/Sp3 (cinko pirštelių motyvus turintys baltymai) transkripcijos aktyvatoriais [17]. Nestrukūrinis baltymas indukuoja apoptozę, nes aktyvina kaspazę 3 ir skatina apoptotinių kūneliu susidarymą, dèl to baltymas yra toksiškas ir sunkiai ekspresuojamas eukariotinèse ir prokariotinèse baltymų raiškos sistemose [18].

Mažiau ištirti yra mažieji nestruktūriniai baltymai 7,5 
$\mathrm{kDa}$ ir $11 \mathrm{kDa}$. 7,5 kDa koduojamas centrinejje genomo dalyje, o $11 \mathrm{kDa} 5$ ' galinèje genomo pusejje. $11 \mathrm{kDa}$ baltymas turi tris prolinu turtingas sekas - Src3 motyvus, branduolio receptorių koaktyvatorius, 3-iojo ligando homologija. Šis baltymas būtinas kapsidès baltymų sintezei infekuotose ląstelèse ir, manoma, kad dalyvauja viruso genomo pakavimo procese. $7,5 \mathrm{kDa}$ baltymo funkcijos nežinomos [3, 19].

Nustatyti 3 parvoviruso genotipai: 1 genotipas - prototipas ir susiję izolatai; 2 genotipas - A6 ir LaLi kamienai ir susiję izolatai; 3 genotipas - V9 kamienas ir susiję izolatai. 1 ir 3 genotipai dar skirstomi i subtipus: 1a, $1 \mathrm{~b}$ ir 3a, 3b [20]. Genotipas 1a yra paplitęs visame pasaulyje, 1b aptinkamas Azijoje. 2 genotipo parvovirusai aptinkami retai, tačiau sutinkami ịvairiuose geografiniuose regionuose. Nustatyta, kad 2 genotipas Europoje buvo paplitęs iki 1960 $\mathrm{m}$., bet vèliau dingo iš šio regiono. Šis genotipas aptiktas tik $2002 \mathrm{~m}$. paciento odos mèginiuose, tačiau vèliau išskirtas ir iš kitų organų [19]. 3 genotipas nustatytas aplastine krize sergančio vaiko kraujyje [21]. 3a ir 3b genotipai nepaplitę Šiaurès Europoje, o dažniausiai sutinkami Vakarų Afrikoje. 3 genotipas paplito tik per paskutinius 70 metuc $[2,20,22]$.

Viruso genotipai skiriasi $\sim 10$ proc. sekų skirtumu. Didžiausi skirtumai nustatyti P6 promotoriaus srityje. Čia DNR sekos skirtumai siekia $>20$ proc., tačiau promotoriaus stiprumas vienodas visuose kamienuose ir aktyviausias permisyviose ląstelèse (kuriose gali daugintis). Poliadenilinimo sekos vienodos visuose trijuose genotipuose. Atviro skaitymo rèmelio DNR sekos skiriasi 9-12 proc., tačiau aminorūgščių skirtumai siekia tik 1,1-1,4 proc. VP1 baltymo unikalaus regiono variabilumas yra didžiausias. 2 genotipo kamienai šiame regione nuo prototipo skiriasi 4,4 proc., o 3 genotipo kamienai - 6,6 proc. Visgi fosfolipazès aktyvumo regionas (130-195) yra labai konservatyvus, o variacijos susitelkusios unikalaus regiono N-gale. NS1 baltymo aktyvūs regionai konservatyviausi, tačiau DNR seka tarp kamienų skiriasi $\sim 13$ proc. ir aminorūgščiu skirtumai siekia $\sim 6$ proc. $11 \mathrm{kDa}$ baltymas skiriasi visuose genotipuose [19].

Ištirta genotipu molekulinè charakteristika. Invertuotu terminalinių pasikartojimų tyrimai parodè, kad 1 genotipo ITP gali replikuoti 3 genotipo virusus, bet ne 2 tipo. Taip pat ištirta, kad tiek 2, tiek 3 genotipo virusų nestruktūrinis baltymas NS1 indukuoja apoptozę infekuotose ląstelèse kaip ir prototipinis virusas. Tuo tarpu 2 genotipo NS1 baltymas nepalaiko 1 genotipo replikacijos. Tarp 1 ir 2 genotipų NS1 baltymų yra 6\% skirtumas, kuris sumažina NS1 galimybes prisijungti prie ITP srities. 2 genotipas taip pat skiriasi tuo, kad neturi A1-2 splaisingo akceptoriaus srities (ivykusi mutacija A i i G). Manoma, kad dèl to išsikerpa didelè genomo sritis ir sumažeja kapsidès baltymų transliacijos aktyvumas [23].
Nepaisant skirtumų, visi kamienai yra vienodos funkcinès charakteristikos. Visi kamienai sukelia hemagliutinaciją. Antikūnai prieš genotipus veikia $100 \%$ kryžmiškai reaktyviai. Kamienų klinikinè svarba nežinoma, tačiau nustatyta, kad 1 genotipo infekcijos metu kraujyje aptinkami daug didesni viruso titrai nei infekavus 2 ir 3 genotipams $[19,23]$.

Patogenezė ir infekcija. Virusas efektyviai patenka ir replikuojasi ląstelèse, kurios turi specifinius receptorius bei yra $\mathrm{S}$ ląstelès ciklo fazeje. Tokios ląstelès yra virusui jautrios ir tinkamos vystymuisi. Parvovirusas B19 infekuoja ir dauginasi $\mathrm{CD} 6^{+}$eritroidinèse kamieninèse ląstelèse raudonujų kraujo kūnelių ląstelèse pirmtakèse. Mèginant užauginti virusą įvairiose ląstelių kultūrose, mokslininkai nustatė, kad virusas dauginasi būtent šiose ląstelèse, nes slopina jų kolonijų formavimąsi. Infekcijos metu virusas sustabdo eritropoezę. Eritroidinès kamieninès ląstelès aptinkamos kaulu čiulpuose, periferiniame kraujyje bei vaisiaus kepenyse [8].

B19 prisijungia ir patenka ị ląstelę panaudodamas tris ląstelinius receptorius. Virusui reikalingas receptorius globozidas (glikosfingolipido tetraheksozès ceramidas) arba kraujo grupès $\mathrm{P}$ antigenas (P-ag) [6]. Virusas negali infekuoti žmonių, turinčių mutaciją $\mathrm{P}$ antigeno gene [17]. $\mathrm{P}$ antigenas ekspresuojamas ant hematopoetiniu kamieninių ląstelių, megakariocitų, eritroblastų, endotelio, kepenų, širdies, plaučių, sinovinės membranos ląstelių [21]. Receptoriaus ekspresija ant kitų audinių ląstelių paaiškina, kaip virusas gali plisti nehematopoetinèse organų sistemose. Receptorius ekspresuojamas eritrocitų paviršiuje, taigi, virusas sukelia raudonųjų kraujo kūnelių agliutinaciją [5]. Virusas patenka ị vaisių ir infekuoja vaisiaus miocitus ir hepatocitus, nes gauruotieji placentos trofoblastai turi globozidą [6]. Globozidas taip pat aptinkamas ir kai kuriuose nežmoginiuose primatuose - krabaèdèse beždžionèse, makakose. Parvovirusas infekuoja globozidą turinčius gyvūnus $[2,24]$. Nustatyta, kad globozido ekspresijos lygis nekoreliuoja su infektyvumu. Taigi, šis receptorius reikalingas viruso prisijungimui, bet ne perèjimui i ląstelę. Efektyviai infekcijai dar reikia bent dviejų koreceptorių. Vienas jų - $\alpha 5 \beta 1$-integrinas, dalyvaujantis ląsteliu adhezijoje ir ekspresuojamas ant eritroidinių ląstelių pirmtakių [21]. Kita molekulė Ku80 - vilkligès autoantigenas, branduolinis baltymas, kuris lokalizuojasi ląstelès membranoje [25].

Prisijungęs prie specifinių receptorių virusas į ląstelę patenka endocitozès būdu. Patekus ị ląstelę endocitozinè vakuolè rūgštinama: dèl V-ATPazių veikimo ì vakuolès vidų pernešami $\mathrm{H}^{+}$jonai. Virusas patenka ị citozoli pasinaudodamas žemu endosomos pH. Parvovirusų VP1 baltymo unikalus regionas turi panašų i A2 fosfolipazès aktyvu- 
mą, kuris aktyvinamas paveikus žemomis $\mathrm{pH}$. Fosfolipaze suardo endocitozinès vakuolès lipidinę membraną. Citozolyje parvovirusas B19 ị branduoli pernešamas tubulino mikrovamzdeliais, dalyvaujant dineinui. VP1 baltymo N-galinejje dalyje esanti branduolinès lokalizacijos seka nukreipia virusą i branduoli. Branduolio pora siekia $39 \mathrm{~nm}$, todèl virusas $(22-24 \mathrm{~nm})$ laisvai pereina per branduolio porą [3].

Neaišku, kaip DNR atpalaiduojama iš kapsidès replikacijai. Mažojo pelių viruso ir adeno asocijuoto viruso 20-30 5' galo nukleotidai išsikiša ị kapsidès išorę. Jei polimeraze panaudoja šią liekaną replikacijos iniciacijai, viruso kapsidès nereikia išardyti. Panašus modelis gali būti pritaikytas parvovirusui B19, tačiau kol kas tai yra tik hipotezè. Replikacija vyksta „,besisukančio rato - plaukų smeigtuko“ (angl. rolling-hairpin) mechanizmu. Dèl palindrominių sekų 3' galas suformuoja plaukų smeigtuko struktūrą, kuri yra replikacijos pražios pradmuo. Replikaciją vykdo DNR delta polimerazè. Grandinè ilginama ir kovalentiškai sujungiama su kito galo 5' plaukų smeigtuko struktūra. NS1 baltymas kerpa susidariusią dvigrandinę DNR per 18 nukleotidų nuo tikrojo 5' galo. Susidaro nauja plaukų smeigtuko struktūra vèl funkcionuojanti kaip replikacijos pradmuo [3].

Eritropoetinas per Epo receptorių aktyvina viruso replikaciją. Kaip eritropoetinas skatina ekspresiją nežinoma. Nustatyta, kad viruso replikacijos reguliacijoje dalyvauja STAT5A ir MEK/ERK signaliniai keliai. Šie signaliniai keliai nulemia eritroidinių kamieninių ląstelių proliferaciją ir diferenciaciją i eritrocitus. STAT5A - aktyvina proliferaciją ir diferenciaciją, MEK/ERK - slopina. Žinoma, kad eritropoetinas per Epo receptorių aktyvina Jak2 kinazę. Jak2 inicijuoja kinazių kaskadą, kuri aktyvuoja STAT5A, MEK/ERK ir PI3K signalinių kelių kinazes. NS1 baltymas sąveikauja su MEK/ERK signalinio kelio dalyviu GrB. Slopina signalini kelią infekcijos metu ir palengvina replikaciją [26]. NS1 baltymas tai pat sustabdo ląstelès ciklą vèlyvojoje $S$ fazèje, nes ląstelinès $S$ fazès faktoriai dalyvauja virusinès DNR replikacijoje. Vèlyvoji S fazès stadija yra tinkamiausia viruso replikacijai [27].

Transkripcija prasideda nuo NS1 baltymo, nes jis dalyvauja vèlyvujų viruso genų ekspresijoje. Po transliacijos baltymas fosforilinamas ir kolokalizuojasi su kitais NS1 citozolyje, kol pernešami ị branduolị. Struktūriniai baltymai sintetinami citozolyje, vèliau jie pernešami ị branduolị. Struktūriniai baltymai ị branduolị pernešami trimerais. VP1 baltymo N-galinè seka koduoja pernešimo ị branduoli signalą.

Branduolyje kapsidès susirenka spontaniškai. DNR inkorporuojama, kol kapside dar pilnai nesusirinkusi. Šiame procese dalyvauja NS1 baltymas. Kapsidès baltymai fosforilinami ir virionai išnešami iš branduolio. Lizavus ląstelę šeimininkę virusai patenka ị aplinką [3].
Aprašyti mechanizmai vyksta parvovirusui B19 jautriose ir tinkamose daugintis ląstelèse. Tačiau virusas gali infekuoti jautrias ląsteles, kurios turi virusui specifiškus receptorius (trombocitai, retikuliocitai, neutrofilai ir kitos baltosios kraujo ląstelès), tačiau negali efektyviai replikuoti. Tokiose ląstelèse nevyksta pilna genų transkripcija [28]. Virusinis promotorius (P6) skatina tik NS1 baltymo ekspresiją, o kapsidès baltymai neekspresuojami (permisyviose (vystymuisi tinkamose) ląstelèse dominuoja kapsidès baltymų raiška). NS1 baltymas yra citotoksiškas ir gali stimuliuoti apoptotinių kūnelių susidarymą. Jo hiperekspresija lemia ląstelès ciklo areštą ir ląstelès žūtį [18]. Nors virusas nereplikuoja, tačiau vis vien sukelia infekuotos ląstelès žūtị $[29,30]$.

B19 parvovirusas patenka ị žmogaus organizmą ir infekuoja įvairių organų sistemų ląsteles. Jose persistuoja labai ilgai arba visą gyvenimą. Dèl šios priežasties viruso DNR galima aptikti kaulų čiulpuose, odoje, sinoviniame skystyje, kepenyse ir miokarde praejjus ilgam laiko tarpui nuo infekcijos [31].

In vitro B19 replikuoja pirminėse žmogaus kaulų čiulpų ląstelèse, tačiau virusas sunkiai dauginasi audinių kultūrose. Parvovirusas B19 replikuoja keliose ląstelių kultūrose: megakarioblastoidinėse ląstelèse (UT7/Epo ląstelių linija ir jos subklonas UT7/Epo-S1) ir eritroidinèse leukeminèse ląstelių linijose (KU812Ep6). Nors virusas dauginasi šiose ląstelių linijose, tačiau viruso produkcija neefektyvi, silpna ir pusiau permisyvi [26].

Imuninis atsakas. Imuninè sistema paprastai greitai ir efektyviai susidoroja su parvoviruso B19 infekcija, nes virusas yra labai imunogeniškas. Buvo manoma, kad virusas veikia „smūgiuok ir bèk“ principu, nes patekęs ị organizmą virusas greitai pasidaugina ir sukelia viremiją, tačiau taip pat greitai sunaikinamas imuninès sistemos. Nustačius, kad po infekcijos virusas persistuoja žmogaus organizmo ląstelése, dabar šis infekcijos tipas ịvardijamas „smūgiuok ir pasilik" veikimu. Virusas lizuoja infekuotas ląsteles ir patenka ị tarpląstelinę ertmę ir kraują. Organizme pasklidusius virionus naikina humoralinis imuninis atsakas. Prieš parvovirusą susidarę antikūnai nuo pakartotinès infekcijos organizmą apsaugo visą gyvenimą (jeigu nepažeidžiama imuninè sistema). Ląstelinis imuninis atsakas nukreiptas prieš infekuotas, bet nelizuotas ląsteles. Bet kokiu atveju, tiek humoralinis, tiek ląstelinis imunitetai svarbūs efektyviam parvoviruso B19 infekcijos nuslopinimui [6].

Humoralinis imunitetas ir infekcija. Nuslopinant parvoviruso infekciją dominuoja humoralinis imuninis atsakas. Humoralinio imuninio atsako metu susidaro antikūnai prieš B19, kurie yra ypač svarbūs imuninès sistemos komponentai antivirusiniam atsakui. Dažniausiai antikūnai infekciją pašalina per keletą savaičių ir susida- 


\section{8}

riusios atminties B ląstelès sukuria ilgalaikị imunitetą [6].

Po viruso infekcijos praejjus 10-14 dienų paciento kraujyje pasirodo pirmieji virusui specifiški antikūnai, priklausantys IgM klasei. IgM aptinkami iki 10 infekcijos savaitès [15]. Virusui infekavus organizmą pirmieji atsiranda IgM. Jei kraujyje aptinkami šie antikūnai, tai rodo ūmią infekcijos stadiją. Netrukus po IgM pasirodo ir IgG antikūnai - 2-3 infekcijos savaitę. IgG antikūnai nulemia ilgalaikę apsaugą. Pakartotinos infekcijos atveju dominuoja IgG, o IgM susidaro daug mažiau [7]. Dominuojančios antikūnų subklasès: IgG1 ir IgG3. Vystantis imunitetui antikūnų subklasès persijungia iš IgG3 ị IgG4 ir IgG2 [32, 33]. Rečiau aptinkami IgA antikūnai, kurie naikina B19 virusą kvèpavimo takuose [6]. IgE nustatyti ankstyviausiose infekcijos stadijose, tačiau jų funkcija B19 parvoviruso infekcijoje nežinoma. Vystantis imuniniam atsakui IgE klasè persijungia ị IgA, todèl jei padaugeja $\operatorname{IgA}$, sumažèja $\operatorname{IgE}$ [34].

Neutralizuojantys IgM ir IgG antikūnai, kurie pasirodo pirmieji, yra specifiški parvoviruso kapsidès baltymams. IgM imuninis atsakas dominuoja prieš VP1 baltymo konformacinius epitopus. Šiek tiek mažiau neutralizuojančių IgM klasės antikūnų susidaro prieš VP1 linijinius ir VP2 konformacinius epitopus. Mažiausiai IgM antikūnų aptinkama prieš VP2 linijinius epitopus. Taip yra dèl to, kad imuninio atsako eigoje IgM klasės antikūnai persijungia i IgG klasès antikūnus prieš VP2 linijinius epitopus [7, 35]. Tolimesniuose imuninio atsako formavimosi etapuose palaipsniui mažèja IgG antikūnų prieš VP2 linijinius epitopus, juos pakeičia antikūnai prieš VP2 ir VP1 baltymų koformacinius epitopus. Vyksta idomus imunologinis fenomenas - antikūnų epitopų pasikeitimas iš linijinių i konformacinius. Praejus 6-12 mènesiams nuo infekcijos jau nebėra antikūnų prieš linijinius epitopus, o susidaro antikūnai prieš konformacinius VP1/VP2 kapsidès epitopus. Tai vyksta dèl to, kad dendritinès ląstelès savo paviršiuje prisijungia virusines daleles ir pateikia B ląstelèms. Taigi, atsiranda galimybe atpažinti konformacinius epitopus ir imuninis atsakas tampa specifiškesnis. Atminties B ląstelès, kurios sukuria ilgalaikị imunitetą, daugiausia atpažịsta konformacinius kapsidès baltymų epitopus [17, 32]. Linijiniai antikūnų epitopai dominuoja tik prieš VP1 baltymo unikalų regioną [6]. Kapsidès paviršiuje išsidèstę VP1u regiono linijiniai epitopai yra gausus epitopu šaltinis humoralinei imuninei sistemai [31].

Virusiniai epitopai yra kapsidès paviršiuje. VP1 baltymo unikalus regionas yra imunodominuojanti baltymo dalis, kurioje susikaupę B ir T ląstelių epitopai [31]. Didžiausias imunoreaktyvumas nustatytas prieš VP1 unikalaus regiono $\mathrm{N}$-galą - prieš šią sritị susidaro daugiausiai IgG klasės antikūnų [36]. Taip pat virusą neutralizuojančių antikūnų atpažistami epitopai yra aplink P antigeno prisijungimo vietą [37]. Stiprus imunoreaktyvumas nustatytas VP2 baltymo C-galiniame domene ir toje sekos srityje, kuri jungia abu kapsidès baltymus. Stiprius ryšius su antikūnais sudaro šiose srityse aptinkamos polilizino liekanos [38].

Antikūnai prieš NS1 baltymą susidaro daug vèliau, praejus apytiksliai 6 savaitèms nuo infekcijos ir tokie antikūnai turi sąsajas su „rimta“ lètine infekcija $[17,39]$. Paprastai šio baltymo nèra daug, nes tai nestruktūrinis baltymas ir imunine sistema menkai i ji reaguoja. Tačiau esant stipriai ir persistuojančiai infekcijai jo ị kraują patenka daugiau. Ligos eigoje ląstelès lizuojamos ir atpalaiduojamas NS1 baltymas, kurị imuninè sistema gali atpažinti. Prieš NS1 susidaro IgG klasès antikūnai. 23 proc. žmonių, kurie buvo infekuoti parvovirusu B19, turi antikūnus prieš NS1. Persistuojančių ir lètinių infekcijų atvejais 80 proc. pacientų turi antikūnus prieš NS1 [29]. Antikūnai susidaro prieš baltymo konformacinius epitopus [5].

Ląstelinis imunitetas ir infekcija. Pagrindinị vaidmenị kovoje su parvovirusu B19 atlieka antikūnai, neutralizuojantys virusą kraujyje, tačiau efektyviam imunitetui susidaryti būtinas ląstelinis imunitetas, kuriame dalyvauja pagalbinès $\mathrm{CD}^{+} \mathrm{T}$ ląstelès (Th limfocitai) ir citotoksinès $\mathrm{CD}^{+} \mathrm{T}$ ląstelès (CTL limfocitai).

$\mathrm{CD}^{+}$limfocitai išskiria citokinus ir taip moduliuoja imuninę sistemą [6]. Citotoksinès $\left(\mathrm{CD} 8^{+}\right) \mathrm{T}$ ląstelès (CTL limfocitai) naikina viruso infekciją pašalindamos infekuotas ląsteles. Po pirminès parvoviruso B19 infekcijos kraujyje pradeda cirkuliuoti atminties $\mathrm{T}$ ląstelès, kurios turi dideli proliferacijos potencialą pakartotinos infekcijos atveju ir greitai ima proliferuoti organizme aptikus virusą [40].

$\mathrm{CD}^{+} \mathrm{T}$ ląstelès perjungia antikūnų klases ir skatina jų afiniškumo brendimą. Jos stimuliuoja B ląsteles ir indukuoja B ląstelių lemiamą antikūnų produkciją, dèl to susidaro ilgalaikis imunitetas [41]. Aktyviausia šiu ląstelių proliferacija ir citokinu produkcija pastebima ankstyvose infekcijos stadijose. Antigeną pateikiančios ląstelès pristato viruso antigenus pradinėms $\mathrm{CD}^{+} \mathrm{T}$ ląstelèms per HLA II molekules. $\mathrm{CD}^{+}$ląstelès, atsakydamos ị antigeną, proliferuoja, produkuoja ịvairius citokinus, kurie reguliuoja imunini atsaką (Franssila ir kiti, 2001). Ex vivo tyrimuose 90 proc. T ląsteliu stimuliuoja VP2, o 80 proc. - VP1 baltymas [17]. Ypač svarbus ląstelinio imuniteto formavimuisi VP1 baltymo unikalus regionas, indukuojantis $\mathrm{CD}^{+}$ląstelių proliferaciją ūminejje infekcijos stadijoje [31]. Tačiau šis atsakas neaptiktas seniai buvusiose infekcijose [41].

Parvoviruso infekcijoje dalyvauja dvi pagalbinių CD4 ${ }^{+}$ ląsteliu grupès (Th1 ir Th2), jos produkuoja skirtingus citokinus ir valdo imunini atsaką. Th1 - atsakingos už uždegiminių reakcijų skatinimą, hiperjautrumą ir ląstelinio 
imuniteto indukciją prieš viduląstelinius patogenus. Jų produkuojami citokinai skatina $\mathrm{CD} 8^{+} \mathrm{T}$ ląstelių diferenciaciją $\dot{i}$ aktyvintus citotoksinius $\mathrm{T}$ leukocitus bei aktyvina makrofagus. Th1 pradeda produkuoti citokinus praejus dviems savaitems nuo B19 infekcijos [42]. Th2 atsakas i B19 infekciją menkai ištirtas. Th2 citokinai pasirodo pirmomis infekcijos dienomis, tačiau menkai produkuojami ūmių ir chronišku infekcijų atveju $[42,43]$. Pirminès infekcijos metu aptinkami tiek Th1, tiek Th2 citokinai [6]. Trečiosios pagalbinių T ląstelių grupès - Th17 limfocitų veikimas B19 parvoviruso infekcijoje netirtas. Šios grupès ląstelès produkuoja uždegiminị citokiną IL-17, kuris siejamas su autoimuninèmis ligomis ir uždegimais [44].

Esant lètinèms ir ūminèms infekcijoms sutrinka citokinų santykis. Esant ūminei parvoviruso B19 infekcijai, yra aptiktas TNFa, IFNg, IL-4, IL-6, IL-2, IL-10, IL-12 padidejjimas kraujo serume. Kai kuriu citokinu (TNFa, IFNg) kiekis laikosi padidèjęs lètinèje fazèje, o taip pat ir po infekcijos [33, 43, 45, 46]. Padidèjęs TNFa kiekis siejamas su tuo, kad NS1 baltymas aktyvina TNFA geno promotoriu, todèl sukelia TNF $\alpha$ hiperprodukciją [33]. Tačiau kai kurie literatūros šaltiniai [45] byloja apie IL-6 ir TNFa kiekio kraujo serume sumažèjimą tuo atveju, kai B19 infekcija sukelia ị reumatoidinị artritą panašius požymius.
$\mathrm{Su}$ viruso infekcija kovoja ir citotoksiniai $\mathrm{CD} 8^{+} \mathrm{T}$ limfocitai (CTL). Citotoksinès ląstelès naikina virusu infekuotas ląsteles. Infekuotos ląstelès pateikia virusinius epitopus per MHC I molekules. Tuomet CTL ląstelès TCR receptorių pagalba atpažista virusinius epitopus ir indukuoja infekuotos ląstelès žūtį [47]. Šios ląstelès kontroliuoja audinių infekcijas, nes ten antikūnai mažiau efektyvūs [48]. CTL ląstelių atsakas dominuoja prieš NS1 baltymo epitopus. Citotoksiniai T limfocitai veikia vos prieš kelis NS1 baltymo epitopus. Dèl tokio siauro TCR repertuaro virusas mutuodamas gali ,pasprukti“ nuo imuninio atsako [47]. Ūminès ir lètinès infekcijos stadijos metu citotoksinès ląstelès veikia labai stipriai, nustatomas CTL ląstelių pikas [6]. Ląsteliu atsakas ilgai trunka po infekcijos. Tai vienas ilgiausiai trunkančių atsakų - aktyvus ląstelinis imunitetas išlieka iki dviejų metų po infekcijos [49]. Tačiau organizme aptinkama nedidelè CTL populiacija net daugeliui metų praejus po B19 infekcijos [47]. Imuninis atsakas ị parvoviruso B19 infekciją susistemintas 2 paveiksle.

Epidemiologija. Virusas paplitęs visame pasaulyje. Besivystančiose šalyse viruso infekcija dažnesnè, nei išsivysčiusiose šalyse. Vidutinio klimato juostose B19 dažniau infekuoja vaikus nei suaugusius [50].

Parvovirusas B19 - vidutiniškai užkrečiamas viru-



2 pav. T ir B ląstelių atsako ị B19 infekciją schema. Po parvoviruso B19 infekcijos B ląstelès proliferuoja, diferen-

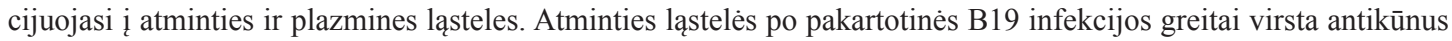
produkuojančiomis plazminèmis ląstelèmis. Plazminės ląstelès produkuoja IgM ir IgG antikūnus, kurie atpažįsta konformacinius (N) ir linijinius (D) kapsidès baltymų (VP1 ir VP2) ir nestruktūrinio baltymo (NS1) epitopus. Antigeną pateikiančios ląstelès (APL) pateikia viruso epitopus naivioms $\mathrm{CD}^{+}{ }^{+}$ir $\mathrm{CD}^{+} \mathrm{T}$ ląstelèms. Aktyvuotos $\mathrm{T}$ ląstelès išskiria citokinus, skatinančius antivirusinius procesus 
sas. Infekcijos yra sezoninès, būdingos žiemos pabaigoje/ pavasario pradžioje. Epidemijos kartojasi kas 3-4 metus. Dažniausiai parvoviruso infekcija žmogus perserga vieną kartą, retais atvejais, dažniausiai sutrikus imunitetui, parvovirusas infekuoja daugiau kartų [51]. Dažniausiai serga mokyklinio amžiaus vaikai [52]. 15\% ikimokyklinio amžiaus vaikų yra serologiškai teigiami (kraujyje aptinkami IgG antikūnai prieš B19), paaugliu - 50 proc., o vyresnio amžiaus žmonių net 85 proc. [6].

Esant infekcijai kraujyje labai išauga virionų skaičius. Jau 5 infekcijos dieną virusas aptinkamas kraujo serume. Viremija piką pasiekia 8 infekcijos dieną, kai virionų skaičius gali siekti $10^{13}$ virionų/mL kraujo. Vèliau virionų skaičius krenta dèl pasirodančių IgM antikūnų [7].

Viruso inkubacinis periodas trunka 4-14 dienų [53]. Infekcijos nešiotojas aplinkinius parvovirusu gali užkrèsti 7-14 infekcijos dienomis [52]. Virusas perduodamas oro lašeliniu būdu, nes organizme virusas kaupiasi kvėpavimo takuose. Taip pat virusas plinta per donorų kraują ar kraujo produktus. B19 labai rezistentiškas ir gali išvengti viruso pašalinimo procedūrų, taikomų donorų kraujui. Nuo 2002 metų kraujo produktai tikrinami dèl parvoviruso B19, perpilant juos rizikos grupèms priklausantiems asmenims. Europos Farmakopejja nustate, kad plazmos produktai laikomi saugiais Europoje, jei neviršija $10^{4}$ viruso dalelių/mL kraujo [54]. Kompanijos stengiasi minimizuoti B19 kieki kraujyje: atskirai išskiria raudonąsias kraujo ląsteles, albuminą ar imunoglobulinus [17].

Rizikos grupėms priklausantiems asmenims viruso infekcija pavojingiausia. Rizikos grupei priskiriami žmonès, kuriems yra hematologiniai sutrikimai, dèl kurių raudonujų kraujo kūnelių gyvenimo trukmè sutrumpẻja. Tai pacientai, sergantys pjautuvine anemija, hemolizine anemija, igimta sferocitoze, taip pat hemofilija [52]. Taip pat asmenys, kurių imuninè sistema yra sutrikusi: sergantys AIDS [55], pacientai, kuriems atliekama organų transplantacija ar perpilami kaulų čiulpai $[9,56]$, onkologiniai ligoniai [57]. Virusas pavojingas serologiškai neigiamoms pagal $\mathrm{IgG}^{-}$prieš B19 něščioms moterims. B19 gali pereiti per placentą ir pažeisti vaisių. Dèl to néščioms moterims patariama vengti kontakto su sergančiaisiais lètine B19 infekcija ir kurių imunitetas yra susilpnėjęs [58].

Infekcijos nustatymas. Viruso infekcija nustatoma serologiškai (antikūnų nustatymas), tiesiogiai (DNR ir viruso baltymų nustatymas) arba histologiškai kraujyje, amniono skystyje, kaulų čiulpuose ar kituose organuose (kepenys, plaučiai, inkstai) [53].

Antikūnus prieš virusą galima nustatyti ELISA, imunoblotingu ir imunofluorescenciniais metodais [59]. Šiems metodams reikia viruso baltymų, jų fragmentų ar virusų kapsidžių. Viruso dalims gauti panaudojamos bakterijų, mielių arba vabzdžių ląstelių ekspresijos sistemos [2]. IgM antikūnų nustatymas rodo ūminę infekcijos stadiją, juos galima aptikti 2-4 ménesius po infekcijos. Ilgesnė $\operatorname{IgM}$ ekspresija gali būti dèl užsitęsusios B19 infekcijos. Tuomet metodai bus nepatikimi nustatant ūminę infekcijos stadiją [60]. IgG antikūnai po infekcijos kraujyje cirkuliuoja visą gyvenimą. Taigi jei žmogus buvo infekuotas, IgG bus aptinkami visada. Tiesa, antikūnų nustatymas gali būti klaidingai neigiamas stiprios viremijos metu. Tokiu atveju imunoglobulinai kraujyje susijungia su virusinèmis dalelèmis, todèl neaptinkami naudojant serologinius metodus. Be to, antikūnai nesusidaro esant nusilpusiam ar pažeistam imunitetui, todèl rezultatai bus klaidingai neigiami [53]. Kartais su detekcijai naudojamais B19 baltymų epitopais kryžmiškai reaktyviai reaguoja tymų, raudonukès, EBV, CMV virusų antikūnai, tuomet rezultatai bus klaidingai teigiami [3].

Polimerazès grandžių reakcija (PGR) - ypač jautrus metodas virusui nustatyti. Naudojami PGR, realaus laiko PGR bei kiekybinès PGR metodai. Kiekybinès PGR metodu aptinkami labai maži parvoviruso DNR kiekiai - 200 IU/mL [20]. Šis metodas leidžia aptikti viruso DNR pacientuose, kurių imunitetas yra pažeistas. Tuomet netinkami serologiniai metodai, be to, viruso DNR aptinkama praejus ilgam laikui nuo infekcijos [53]. PGR naudojamas vaisiaus amniono skysčio tyrimuose. PGR metodu tiriamos neseniai buvusios infekcijos kraujo serume. Iš kraujo serumo parvoviruso DNR pasišalina praejjus 9 mènesiams nuo vireminès fazès [60]. Metodas netinka identifikuoti ūminę infekciją audiniuose ir kraujyje. Be to, dèl genotipų sekų skirtumų PGR gali duoti klaidingai neigiamus rezultatus [53].

ELISPOT metodu galima tirti susidariusias atminties B ir T ląsteles. Šiuo metodu nustatomos B ląstelès, kurios produkuoja antikūnus prieš B19, o taip pat ir T ląstelès, kurios atpažista viruso antigenus. Dar vienas metodas hemagliutinacija. Virusinès dalelès jungiasi prie eritrocitu paviršiuje ekspresuojamu $\mathrm{P}$ antigenu receptoriu ir sukelia eritrocitų hemagliutinaciją. Tačiau tai labai nejautrus metodas ir retai taikomas [59]. Virusas sunkiai auga ląsteliu kultūrose, todèl ląstelių kultūrų auginimas viruso nustatymui netaikomas [61].

Klinikiniai aspektai. Parvoviruso B19 infekcija 25 proc. infekuotų žmonių nesukelia jokių simptomų. Ryškiausias klinikinis požymis yra bėrimai, kurie pasireiškia 50 proc. infekcijų. Pirmieji simptomai pasirodo pirmają infekcijos savaitę ir gali trukti 2-3 dienas. Paprastai B19 infekcija primena gripą: peršalimas, karščiavimas, jaučiamas galvos bei raumenų skausmas. Šie požymiai sutampa su viremijos piku. Tuo metu pasireiškia raudonujų kraujo 


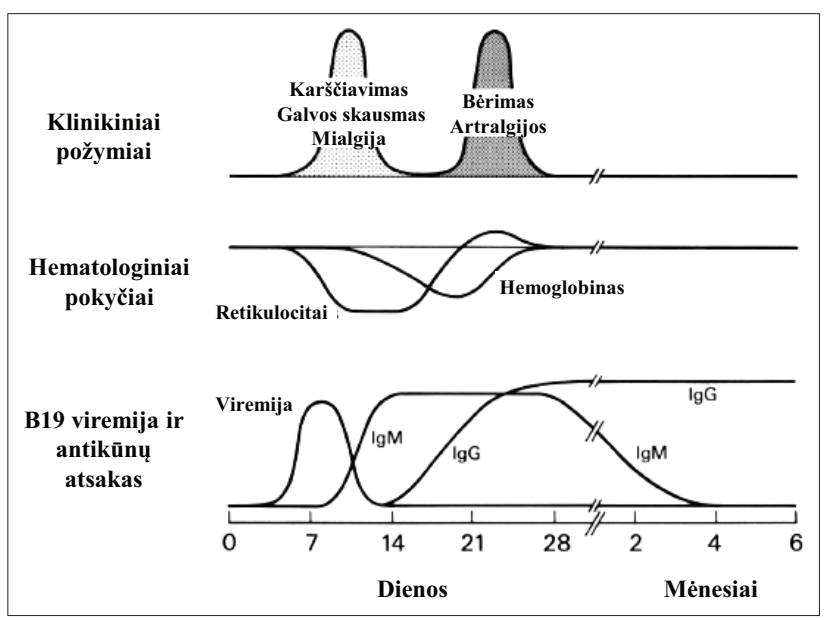

3 pav. Parvoviruso B19 infekcijos virusologine, imunologinė ir klinikinè raida [5]

kūnelių aplazija (staigus raudonųų kraujo kūnelių brendimo nutrūkimas), retikulocitopenija, lengva limfopenija, trombocitopenija ir neutropenija. Kiek véliau sumažèja hemoglobino kiekis. Hemoglobino kiekio pokyčiai nesutampa su viremija, nes eritrocitu gyvenimo trukmé ilgesné, dèl to viremijos stadijoje dar nejuntamas jų kiekio sumažéjimas. IgM ir IgG pasirodo 10-14 infekcijos dienomis, baigiantis viremijos periodui (3 pav.). Kraujyje susidaro imuniniai kompleksai ir tai sutampa su bérimais ir artralgijomis. Jei imunitetas nesutrikęs ir neišsivysto komplikacijos, visi simptomai praeina per kelias savaites ir nesukelia rimtesnių pažeidimų $[1,3]$.

Parvoviruso B19 sukeliamos ligos. Infekcinė eritema (EI). Pusei infekuotų vaikų infekcija yra asimptominé, tačiau 25-50 proc. infekuotų vaikų pasireiškia „raudonų skruostų" sindromas arba infekciné eritema. Tai yra viena iš šešių vaikiškų egzantemų (kartu su tymais, skarlatina, raudonuke, Duko liga ir rozeola). Pagal atradimo eiliškumą dar vadinama penktaja liga [8]. Ligai būdingi bẻrimai su papulèmis: paraudę, nuberti skruostai, taip pat beria kaklą, kūną ir galūnes. EI pasireiškia pacientams, kuriems nèra sutrikęs imunitetas, nes bèrimai susidaro dèl antigenųantikūnų kompleksų kaupimosi paciento odoje. Bèrimai paprastai praeina po 1-2 savaičių, tačiau dèl dirgiklių gali atsinaujinti. Simptomai atsinaujina atliekant fizinius pratimus, maudantis, streso sąlygomis, būnant saulès šviesoje. Retais atvejais bérimai gali trukti kelis mènesius $[6,50]$. Suaugusiesiems taip pat pasitaiko bėrimai, tačiau rečiau ir jiems nebūdingas „raudonų skruostų“ sindromas [62].

Artropatijos. Parvoviruso B19 infekcija siejama su artropatijomis (sąnarių ligomis), kuri sukelia artralgijas (sąnarių skausmus). Suaugusiesiems, dažniau vidutinio amžiaus moterims, išsivysto su B19 susijusios artropatijos [50]. Sąnarių sinoviniame skystyje kaupiasi antikūnų-antigenų kompleksai, kurie sukelia pažeidimus (Hemauer ir kiti, 2000). Sąnarių skausmai pasireiškia 60 proc. infekuotų moteru ir 30 proc. vyrų bei 5 proc. sergančių vaiku $[5,40]$. Artritas dažniausiai ūmus, simetriškas, poliartropatinis, pažeidžiantis rankas ( 75 proc.), riešus (55 proc.), kelius (65 proc.) ir kulkšnis (40 proc.) [62]. Suaugusiesiems artropatijos praeina per 2-3 savaites, nors gali trukti mènesius, vaikams gali trukti iki 1-2 mėnesių. Su virusu susijusios artropatijos yra trumpalaikès ir save limituojančios, tačiau 20 proc. atvejų išsivysto lètiniai artritai $[6,62,63]$.

B19 persistuoja sinovinès membranos ląstelèse ir kaulų čiulpuose [30]. Infekuotos ląstelès skatina citokinų išsiskyrimą ir pritraukia imuninès sistemos ląsteles. Be to, sąnariuose kaupiasi imuniniai kompleksai, kurie gali aktyvinti autoimunines reakcijas, komplementą ir citokinu produkciją [29].

Anemija ir laikina aplastinė krizè. Parvovirusas replikuoja eritroidinèse kamieninèse ląstelèse ir pažeidžia eritropoezę. Sveikiems žmonẻms eritrocitų kiekio sumažejimas yra nežymus ir rimtos anemijos nesivysto. Tačiau jeigu pacientai serga hematologinemis ligomis ar infekcijomis, jiems gali pasireikšti lètinè retikulocitopenija (retikulocitų kiekio sumažèjimas). Tokių pacientų kraujyje nėra naujų eritrocitų, o kaulų čiulpuose visi normoblastai tampa gigantiškais pronormoblastais. Jei taip nutinka, hemoglobino kiekis pasiekia kritinę ribą, kuri gali būti mirtina [8, 16].

Virusas persistuoja kaulų čiulpuose ir infekuoja ir kitas kaulų čiulpų ląsteles. Nors jose nesidaugina, NS1 baltymas indukuoja apoptozę ir ląstelès žūna. Sutrinka ne tik eritrocitų, bet ir baltujų kraujo kūnelių (leukopenija, neutropenija) bei trombocitu (trombocitopenija) produkcija [61]. Vystosi laikina aplastinè krizè - visų kraujo kūnelių kiekio sumažèjimas, kuris gali būti mirtinas. Aplastinè krizè taip pat sukelia širdies, cerebrovaskuliarinius, blužnies sutrikimus [8].

Rizikos grupei priklauso pacientai, kuriems yra hematologinių sutrikimų (hemolizinè anemija, talasemija, pjautuvinè anemija, geležies deficitas, igimta sferocitozè, hemoragija, maliarija) [6].

Rizikos grupei priskiriami ir imunodeficitiniai pacientai. Jų humoralinis ir ląstelinis imunitetai sutrikę, dèl to organizmas negali kovoti su viruso infekcija. Tai sukelia pastovią ir lètinę infekciją, virusas lengvai pažeidžia organizmą. Tokiems pacientams dažniau išsivysto laikina aplastinè krizè, rimtos anemijos, pažeidžiami kaulų čiulpai. Imunitetas negali nuslopinti infekcijos ị kaulų čiulpų ląsteles. Kadangi kraujyje nèra antikūnų, nesiformuoja antikūnų-antigenų kompleksai, dèl to šiems pacientams ne- 
pasireiškia bėrimai ir artralgijos. Rizikos grupei priklauso pacientai, sergantys įvairiais imunodeficitais, limfine leukemija, AIDS, onkologinemis ligomis. B19 infekcija pavojinga pacientams, kurių imunitetas susilpnintas dirbtinai - transplantacijos ar chemoterapijos atveju [17, 57, 64-66].

Vaisiaus pažaidos. Parvovirusas gali infekuoti vaisių, jei motina neturi antigenų prieš parvovirusą. Rizikos grupę sudaro apie 35 proc. néščiujų. B19 užsikrečia 1,5 proc. (normaliomis sąlygomis) ir 13 proc.(epidemijų metu) nèščiujų. Iš jų 33 proc. atvejų vyksta vertikali transmisija ir vaisius infekuojamas. Pažaidos sukeliamos 10 proc. infekuotų vaisių [16, 67].

Něštumo metu motinos imunitetas yra nuslopintas. Susilpninamas Th1 reguliuojamas imunitetas, kad vaisius nebūtų atmestas. Imuninè sistema nepajègia efektyviai pašalinti viruso infekcijos [29]. Virusas gali pažeisti vaisių iki 20 něštumo savaitès. Vaisiaus komplikacijos pasireiškia praejus 2-4 savaitėms po motinos infekcijos. Viruso DNR tuo metu aptinkama vaisiaus audiniuose ir placentoje. Vaisiaus antikūnai veikia labai silpnai, nes vaisiaus imuniné sistema dar pilnai nesusiformavusi. Nuo 20 savaitès vaisiaus imuninè sistema produkuoja nedidelius kiekius IgM klasès antikūnų. Papildomai antikūnų motina perduoda per placentą $[58,67]$.

Gauruotieji placentos trofoblastai turi $\mathrm{P}$ antigeną, todèl B19 pereina placentą ir infekuoja vaisių. Pirmojo trimestro metu $\mathrm{P}$ antigenas ekspresuojamas gausiai, todèl užsikrėsti yra didžiausia rizika. Vèliau P antigeno kiekis mažejja, o trečiajame trimestre beveik neaptinkamas [17].

Virusas infekuoja vaisiaus kepenis ir vaisiaus širdies ląsteles - miocitus. Vystymosi metu kepenyse vyksta eritropoezè, o miocitai ekspresuoja $\mathrm{P}$ antigeną. Infekcija gali būti besimptomé, tačiau kartais sukelia vaisiaus anemiją, neimuninę vaisiaus vandenligę, širdies sutrikimus, miokarditą (disritmija ir širdies sustojimas). Tai gali lemti spontanini abortą. Dažniausiai vaisius žūna antrame nèštumo trimestre. Šiuo laikotarpiu raudonujų kraujo kūnelių kiekis sumažejęs, jų išgyvenimo laikas sutrumpèjęs iki 47-70 dienų. Pačios ląstelès padidejusios 3-4 kartus, o vaisiaus imuninè sistema dar nesusiformavusi. Trečiame trimestre hematopoezė persikelia ị kaulų čiulpus, o eritrocitai normalizuojasi. Taigi, sumažeja tikimybè, kad formuosis anemijos ir širdies pažaidos. Vaisiaus vandenlige dažniausiai pasireiškia antroje něštumo pusejje. Parvovirusas sukelia apie 10-20 proc. vaisiaus vandenligių [8, 31, 58].

Pirmame trimestre 3 proc. vaisiaus infekcijų baigiasi spontaniniu abortu. Antrame trimestre 12 proc. pasireiškia vaisiaus vandenlige ir ištinka vaisiaus mirtis. Trečiame trimestre 7 proc infekcijų lemia vaisiaus žūtį. Europoje apie 1,2 milijono moterų per metus gali būti infekuotos. Vai- sių praranda 0,2 proc., taigi, apie 3000 kūdikių [17, 67].

Parvoviruso B19 ryšys su kitomis ligomis. Parvovirusas B19 plačiau paplitęs tarp tam tikromis ligomis sergančių pacientų, nei tarp sveikų žmonių. Parvovirusas B19 dažniau aptinkamas sergant reumatoidiniu artritu $[15,21$, 68], sistemine vilklige [69], lètinio nuovargio sindromu [46, 70-72], kardiomiopatija [73, 74], infekcine eritema [8]. B19 nèra vienintelis veiksnys, sukeliantis šias ligas, tačiau, manoma, kad virusas prisideda prie jų patogenezės ir skatina ligos sunkesnès formos vystymąsi.

\section{Apibedrinimas}

Parvovirusas B19 jau keletą dešimtmečių pasaulyje tiriamas virusas. Nuo viruso atradimo 1975 metais mokslininkai visame pasaulyje apie ši virusą sukaupe daug vertingos informacijos. Nustatyta viruso struktūra, patogenezé, atlikta daug imuninio atsako ị infekciją tyrimų, išanalizuotos viruso sukeliamos pažaidos, paplitimas bei sukurti viruso nustatymo metodai. Nepaisant to, Lietuvoje šis virusas dar mažai tirtas ir apie ji nedaug žinoma.

Virusas yra paplitęs visame pasaulyje. Infekcija persergama vaikystèje ir susidarę antikūnai apsaugo nuo kitu infekcijų. Paprastai virusas nesukelia rimtų sutrikimų. Vaikams pasireiškia berimai, o suaugusiems sąnarių skausmai. Dažnai infekcija būna besimptomè.

Šis virusas yra vienas mažiausių žmones infekuojančių virusų. Virusas pasižymi specifiškumu raudoniesiems kraujo kūneliams ir sukelia nepaprastai aukštą viremiją. Aukšta viremija ir kraujo kūnelių pažeidimas yra priežastys, dèl kurių virusas sukelia ịvairius sutrikimus - dèl aukštos viremijos stipriai aktyvinama imuninè sistema, ir imuninių kompleksų susidarymas sukelia bėrimus bei sąnarių pažeidimus. Tai būdingiausi parvoviruso B19 infekcijos simptomai. Taip pat virusas pavojingas rizikos grupèms asmenims, kuriems yra hematologinių bei imuninių sutrikimų bei něščioms moterims. Būtent dẻl rizikos grupių buvo susirūpinta viruso sukeliamomis pažaidomis ir stengiamasi apsaugoti šias rizikos grupes. Jau daugiau nei dešimtmeti Europoje stengiamasi užtikrinti, kad virusas neplistu per kraujo produktus, o serologiškai neigiamos néščiosios būtų ištirtos ir informuotos dèl galimos rizikos.

Iki šiol virusas tiriamas ịvairiais serologiniais bei molekulinès biologijos metodais. Viruso infekcijos tyrimai yra gana gerai išvystyti ir tai padeda plačiau tirti bei susipažinti su parvovirusu B19.

Atsižvelgus ị literatūrą, galime teigti, kad, nepaisant to, kad parvovirusas yra labai mažas, jis gali būti svarbus svarbus ịvairių ligų patogenezejje. 


\section{Literatūra}

1. Haaheim L, Pattison J, Whitley R. A practical guide to clinical virology, 2 edn. England: John Wiley \& Sons, 2002.

2. Brown KE. The expanding range of parvoviruses which infect humans. Reviews in medical virology 2010; 20(4):231-244.

3. Knipe DM HP. Fields Virology, 5 edn. Philadelphia: Lippincott Williams \& Wilkins, 2007.

4. Cossart YE, Field AM, Cant B, Widdows D. Parvovirus-like particles in human sera. Lancet 1975; 1(7898):72-73.

5. Heegaard ED, Rasksen CJ, Christensen J. Detection of parvovirus B19 NS1-specific antibodies by ELISA and western blotting employing recombinant NS1 protein as antigen. Journal of medical virology 2002; 67(3):375-383.

6. Broliden K, Tolfvenstam T, Norbeck O. Clinical aspects of parvovirus B19 infection. Journal of internal medicine 2006; 260(4):285-304.

7. von Landenberg P, Lehmann HW, Modrow S. Human parvovirus B19 infection and antiphospholipid antibodies. Autoimmunity reviews 2007; 6(5):278-285.

8. Young NS, Brown KE. Parvovirus B19. The New England journal of medicine 2004; 350(6):586-597.

9. Rahiala J, Koskenvuo M, Norja P, Meriluoto M, Toppinen M, Lahtinen A, Vaisanen E, Waris M, Vuorinen T, Saarinen-Pihkala U. et al. Human parvoviruses B19, PARV4 and bocavirus in pediatric patients with allogeneic hematopoietic SCT. Bone marrow transplantation 2013; 48(10):1308-1312.

10. Shade RO, Blundell MC, Cotmore SF, Tattersall P, Astell CR. Nucleotide sequence and genome organization of human parvovirus B19 isolated from the serum of a child during aplastic crisis. Journal of virology 1986; 58(3):921-936.

11. Yaegashi N, Shiraishi H, Takeshita T, Nakamura M, Yajima A, Sugamura K. Propagation of human parvovirus B19 in primary culture of erythroid lineage cells derived from fetal liver. Journal of virology 1989; 63(6):2422-2426.

12. Brown KE, Anderson SM, Young NS. Erythrocyte P antigen: cellular receptor for B19 parvovirus. Science 1993; 262(5130):114-117.

13. Sato H, Hirata J, Furukawa M, Kuroda N, Shiraki H, Maeda Y, Okochi K. Identification of the region including the epitope for a monoclonal antibody which can neutralize human parvovirus B19. Journal of virology 1991; 65(4):1667-1672.

14. Sato H, Hirata J, Kuroda N, Shiraki H, Maeda Y, Okochi K. Identification and mapping of neutralizing epitopes of human parvovirus B19 by using human antibodies. Journal of virology 1991; 65(10):5485-5490.

15. Lehmann HW, von Landenberg P, Modrow S. Parvovirus B19 infection and autoimmune disease. Autoimmunity reviews 2003; 2(4):218-223.

16. Chandramouli S, Medina-Selby A, Coit D, Schaefer M, Spencer T, Brito LA, Zhang P, Otten G, Mandl CW, Mason PW. et al. Generation of a parvovirus B19 vaccine candidate. Vaccine 2013; 31(37):3872-3878.

17. Corcoran A, Doyle S. Advances in the biology, diagnosis and host-pathogen interactions of parvovirus B19. Journal of medical microbiology 2004; 53(Pt 6):459-475.

18. Thammasri K, Rauhamaki S, Wang L, Filippou A, Kivovich V, Marjomaki V, Naides SJ, Gilbert L. Human parvovirus B19 induced apoptotic bodies contain altered self-antigens that are phagocytosed by antigen presenting cells. PloS one 2013; 8(6):e67179.

19. Ekman A, Hokynar K, Kakkola L, Kantola K, Hedman L, Bonden H, Gessner M, Aberham C, Norja P, Miettinen S. et al. Biological and immunological relations among human parvovirus B19 genotypes 1 to 3. Journal of virology 2007; 81(13):6927-6935.

20. Bonvicini F, Manaresi E, Bua G, Venturoli S, Gallinella G. Keeping pace with parvovirus B19 genetic variability: a multiplex genotype-specific quantitative PCR assay. Journal of clinical microbiology 2013; 51(11):3753-3759.

21. Lunardi C, Tinazzi E, Bason C, Dolcino M, Corrocher R, Puccetti A. Human parvovirus B19 infection and autoimmunity. Autoimmunity reviews 2008; 8(2):116-120.

22. Norja P, Hokynar K, Aaltonen LM, Chen R, Ranki A, Partio EK, Kiviluoto O, Davidkin I, Leivo T, Eis-Hubinger AM et al. Bioportfolio: lifelong persistence of variant and prototypic erythrovirus DNA genomes in human tissue. Proceedings of the National Academy of Sciences of the United States of America 2006; 103(19):7450-7453.

23. Chen Z, Guan W, Cheng F, Chen AY, Qiu J. Molecular characterization of human parvovirus B19 genotypes 2 and 3. Virology 2009; 394(2):276-285.

24. Gallinella G, Anderson SM, Young NS, Brown KE. Human parvovirus B19 can infect cynomolgus monkey marrow cells in tissue culture. Journal of virology 1995; 69(6):3897-3899.

25. Aslanidis S, Pyrpasopoulou A, Kontotasios K, Doumas S, Zamboulis C. Parvovirus B19 infection and systemic lupus erythematosus: Activation of an aberrant pathway? European journal of internal medicine 2008; 19(5):314-318.

26. Chen AY, Kleiboeker S, Qiu J. Productive parvovirus B19 infection of primary human erythroid progenitor cells at hypoxia is regulated by STAT5A and MEK signaling but not HIFalpha. PLoS pathogens 2011; 7(6):e1002088.

27. Luo Y, Kleiboeker S, Deng X, Qiu J. Human parvovirus B19 infection causes cell cycle arrest of human erythroid progenitors at late $\mathrm{S}$ phase that favors viral DNA replication. Journal of virology 2013; 87(23):12766-12775.

28. Liu JM, Green SW, Shimada T, Young NS. A block in fulllength transcript maturation in cells nonpermissive for B19 parvovirus. Journal of virology 1992; 66(8):4686-4692.

29. Hemauer A, Gigler A, Searle K, Beckenlehner K, Raab U, Broliden K, Wolf H, Enders G, Modrow S. Seroprevalence of parvovirus B19 NS1-specific IgG in B19-infected and uninfected individuals and in infected pregnant women. Journal of medical virology 2000; 60(1):48-55.

30. Mitchell LA, Leong R, Rosenke KA. Lymphocyte recognition of human parvovirus B19 non-structural (NS1) protein: associations with occurrence of acute and chronic arthropathy? 


\section{4}

Journal of medical microbiology 2001; 50(7):627-635.

31. Lindner J, Barabas S, Saar K, Altmann D, Pfister A, Fleck M, Deml L, Modrow S. CD4(+) T-cell responses against the VP1-unique region in individuals with recent and persistent parvovirus B19 infection. Journal of veterinary medicine B, Infectious diseases and veterinary public health 2005 ; 52(78):356-361.

32. Corcoran A, Doyle S, Waldron D, Nicholson A, Mahon BP. Impaired gamma interferon responses against parvovirus B19 by recently infected children. Journal of virology 2000; 74(21):9903-9910.

33. Kerr JR, Barah F, Mattey DL, Laing I, Hopkins SJ, Hutchinson IV, Tyrrell DA. Circulating tumour necrosis factor-alpha and interferon-gamma are detectable during acute and convalescent parvovirus B19 infection and are associated with prolonged and chronic fatigue. The Journal of general virology 2001; 82(Pt 12):3011-3019.

34. Bluth MH, Norowitz KB, Chice S, Shah VN, Nowakowski M, Durkin HG, Smith-Norowitz TA. IgE, CD8(+)CD60+ T cells and IFN-alpha in human immunity to parvovirus B19 in selective IgA deficiency. Human immunology 2005; 66(10):1029-1038.

35. Manaresi E, Zuffi E, Gallinella G, Gentilomi G, Zerbini M, Musiani M. Differential IgM response to conformational and linear epitopes of parvovirus B19 VP1 and VP2 structural proteins. Journal of medical virology 2001; 64(1):67-73.

36. Musiani M, Manaresi E, Gallinella G, Venturoli S, Zuffi E, Zerbini M. Immunoreactivity against linear epitopes of parvovirus B19 structural proteins. Immunodominance of the amino-terminal half of the unique region of VP1. Journal of medical virology 2000; 60(3):347-352.

37. Kerr S, O'Keeffe G, Kilty C, Doyle S. Undenatured parvovirus B19 antigens are essential for the accurate detection of parvovirus B19 IgG. Journal of medical virology 1999; 57(2):179-185.

38. Saikawa T, Anderson S, Momoeda M, Kajigaya S, Young NS. Neutralizing linear epitopes of B19 parvovirus cluster in the VP1 unique and VP1-VP2 junction regions. Journal of virology 1993; 67(6):3004-3009.

39. Kerr JR, Cunniffe VS. Antibodies to parvovirus B19 nonstructural protein are associated with chronic but not acute arthritis following B19 infection. Rheumatology (Oxford) 2000; 39(8):903-908.

40. Isa A, Kasprowicz V, Norbeck O, Loughry A, Jeffery K, Broliden K, Klenerman P, Tolfvenstam T, Bowness P. Prolonged activation of virus-specific CD8+T cells after acute B19 infection. PLoS medicine 2005; 2(12):e343.

41. Franssila R, Hedman K. T-helper cell-mediated interferon-gamma, interleukin-10 and proliferation responses to a candidate recombinant vaccine for human parvovirus B19. Vaccine 2004; 22(27-28):3809-3815.

42. Bluth MH, Norowitz KB, Chice S, Shah VN, Nowakowski M, Josephson AS, Durkin HG, Smith-Norowitz TA. Detection of IgE anti-parvovirus B19 and increased CD23+ B cells in parvovirus B19 infection: relation to Th2 cytokines. Clin Immunol 2003; 108(2):152-158.
43. Isa A, Lundqvist A, Lindblom A, Tolfvenstam T, Broliden K. Cytokine responses in acute and persistent human parvovirus B19 infection. Clinical and experimental immunology 2007; 147(3):419-425.

44. Korn T, Bettelli E, Oukka M, Kuchroo VK. IL-17 and Th17 Cells. Annual review of immunology 2009; 27:485-517.

45. Kerr JR, Cunniffe VS, Kelleher P, Coats AJ, Mattey DL. Circulating cytokines and chemokines in acute symptomatic parvovirus B19 infection: negative association between levels of pro-inflammatory cytokines and development of B19-associated arthritis. Journal of medical virology 2004; 74(1):147-155.

46. Chapenko S, Krumina A, Logina I, Rasa S, Chistjakovs M, Sultanova A, Viksna L, Murovska M. Association of active human herpesvirus-6, -7 and parvovirus b19 infection with clinical outcomes in patients with myalgic encephalomyelitis/chronic fatigue syndrome. Advances in virology 2012; 2012:205085.

47. Kasprowicz V, Isa A, Jeffery K, Broliden K, Tolfvenstam T, Klenerman P, Bowness P. A highly restricted T-cell receptor dominates the $\mathrm{CD} 8+\mathrm{T}$-cell response to parvovirus $\mathrm{B} 19$ infection in HLA-A*2402-positive individuals. Journal of virology 2006; 80(13):6697-6701.

48. Tolfvenstam T, Oxenius A, Price DA, Shacklett BL, Spiegel HM, Hedman K, Norbeck O, Levi M, Olsen K, Kantzanou M. et al. Direct ex vivo measurement of CD8(+) T-lymphocyte responses to human parvovirus B19. Journal of virology 2001; 75(1):540-543.

49. Norbeck O, Isa A, Pohlmann C, Broliden K, Kasprowicz V, Bowness P, Klenerman P, Tolfvenstam T. Sustained CD8+ Tcell responses induced after acute parvovirus B19 infection in humans. Journal of virology 2005; 79(18):12117-12121.

50. Exindari M, Chatzidimitriou D, Melidou A, Gioula G, Ziogou L, Diza E. Epidemiological and clinical characteristics of human parvovirus B19 infections during 2006-2009 in Northern Greece. Hippokratia 2011; 15(2):157-160.

51. Kaufmann J, Buccola JM, Stead W, Rowley C, Wong M, Bates CK. Secondary symptomatic parvovirus B19 infection in a healthy adult. Journal of general internal medicine 2007; 22(6):877-878.

52. Weir E. Parvovirus B19 infection: fifth disease and more. CMAJ : Canadian Medical Association journal = journal de l'Association medicale canadienne 2005; 172(6):743.

53. Eid AJ, Chen SF, Practice ASTIDCo. Human parvovirus B19 in solid organ transplantation. American journal of transplantation : official journal of the American Society of Transplantation and the American Society of Transplant Surgeons 2013; 13 Suppl 4:201-205.

54. Zhang W, Ke L, Changqing L, Zhang Y, Li W. Parvovirus B19V DNA contamination in Chinese plasma and plasma derivatives. Journal of translational medicine 2012; 10:194.

55. Sterpu R, Ichou H, Mahe I, Mortier E. [Reactivation of parvovirus B19 infection in an HIV-infected woman.]. La Revue de medecine interne / fondee par la Societe nationale francaise de medecine interne 2013.

56. Plentz A, Wurdinger M, Kudlich M, Modrow S. Low-level 
DNAemia of parvovirus B19 (genotypes 1-3) in adult transplant recipients is not associated with anaemia. Journal of clinical virology : the official publication of the Pan American Society for Clinical Virology 2013; 58(2):443-448.

57. Li Y, Dong Y, Jiang J, Yang Y, Liu K, Li Y. High prevelance of human parvovirus infection in patients with malignant tumours. Oncology letters 2012; 3(3):635-640.

58. Weiffenbach J, Bald R, Gloning KP, Minderer S, Gartner BC, Weidner A, Hanke M, Enders M. Serological and virological analysis of maternal and fetal blood samples in prenatal human parvovirus b19 infection. The Journal of infectious diseases 2012; 205(5):782-788.

59. Doyle S. The detection of parvoviruses. Methods Mol Biol 2011; 665:213-231.

60. Munksgaard. Human parvovirus B19. American journal of transplantation : official journal of the American Society of Transplantation and the American Society of Transplant Surgeons 2004; 4 Suppl 10:92-94.

61. Mahy B, van Regenmortel M. Desk encyclopedia of general virology. Elsevier-Academic Press: Elsevier-Academic Press, 2010.

62. Tello-Winniczuk N, Diaz-Jouanen E, Diaz-Borjon A. Parvovirus B19-associated arthritis: report on a community outbreak. Journal of clinical rheumatology : practical reports on rheumatic \& musculoskeletal diseases 2011; 17(8):449-450.

63. Takahashi Y, Murai C, Shibata S, Munakata Y, Ishii T, Ishii K, Saitoh T, Sawai T, Sugamura K, Sasaki T. Human parvovirus B19 as a causative agent for rheumatoid arthritis. Proceedings of the National Academy of Sciences of the United States of America 1998; 95(14):8227-8232.

64. von Poblotzki A, Gerdes C, Reischl U, Wolf H, Modrow S. Lymphoproliferative responses after infection with human parvovirus B19. Journal of virology 1996; 70(10):7327-7330.

65. Manaresi E, Gallinella G, Zerbini M, Venturoli S, Gentilomi G, Musiani M. IgG immune response to B19 parvovirus VP1 and VP2 linear epitopes by immunoblot assay. Journal of medical virology 1999; 57(2):174-178.

66. Lee YM, Chuang SY, Wang SF, Lin YT, Chen YM. Epidemiology of human herpesvirus type 8 and parvovirus B19 infections and their association with HIV-1 among men who have sex with men and injection drug users in Taiwan. Journal of microbiology, immunology, and infection = Wei mian yu gan ran za zhi 2013.

67. Zegarac Z, Duic Z, Borovecki A. Recent parvovirus B19 infection in late pregnancy. International journal of gynaecology and obstetrics: the official organ of the International Federation of Gynaecology and Obstetrics 2013; 122(3):262-263.

68. Kozireva SV, Zestkova JV, Mikazane HJ, Kadisa AL, Kakurina NA, Lejnieks AA, Danilane IN, Murovska MF. Incidence and clinical significance of parvovirus B19 infection in patients with rheumatoid arthritis. The Journal of rheumatology 2008; 35(7):1265-1270.

69. Rigante D, Mazzoni MB, Esposito S. The cryptic interplay between systemic lupus erythematosus and infections. Autoimmunity reviews 2014; 13(2):96-102.
70. Kerr JR, Mattey DL. Preexisting psychological stress predicts acute and chronic fatigue and arthritis following symptomatic parvovirus B19 infection. Clinical infectious diseases : an official publication of the Infectious Diseases Society of America 2008; 46(9):e83-87.

71. Fremont M, Metzger K, Rady H, Hulstaert J, De Meirleir K. Detection of herpesviruses and parvovirus B19 in gastric and intestinal mucosa of chronic fatigue syndrome patients. In vivo 2009; 23(2):209-213.

72. Devanur LD, Kerr JR. Chronic fatigue syndrome. Journal of clinical virology : the official publication of the Pan American Society for Clinical Virology 2006; 37(3):139-150.

73. Streitz M, Noutsias M, Volkmer R, Rohde M, Brestrich G, Block A, Klippert K, Kotsch K, Ay B, Hummel M. et al. NS1 specific CD8+ T-cells with effector function and TRBV11 dominance in a patient with parvovirus B19 associated inflammatory cardiomyopathy. PloS one 2008; 3(6):e2361.

74. Zedtwitz-Liebenstein K, Robak O, Burgmann H, Frass M. Retrospective evaluation of antibody index of human parvovirus B19 as a prognostic factor in patients with dilated and ischemic cardiomyopathy. Journal of medical virology 2013; 85(6):1111-1114.

\section{PARVOVIRUS B19: STRUCTURE, PATHOGENESIS, EPIDEMIOLOGY, IMMUNE RESPONSE}

M. Naciūtè, D. Mieliauskaitė, I. Girkontaitė

Key words: parvovirus B19, immune response, pathogenesis, infection, epidemiology.

Summary

Parvovirus B19 is one of smallest DNA virus that infects mammalian cells. It is spread worldwide. This virus is spread by respiratory droplets and by the blood of donors. Many people have parvovirus B19 infection in their childhood and therefore adults already have IgG class antibodies against parvovirus B19. Usually parvovirus B19 infection causes mild symptoms, often the infection is asymptomatic. Parvovirus B19 causes for children erythema infectiosum, whereas adults are diagnosed with arthropathy and arthralgia. Parvovirus is dangerous for people with immune and hematologic disorders; severe anemia can be developed because of B19. Virus is hazardous for pregnant women as it may induce damage of the fetus, hydrops fetalis and miscarriage. Parvovirus B19 infection is often detected together with some other diseases as rheumatoid arthritis, systemic lupus erythematosus, chronic fatigue syndrome, cardiomyopathy. However is not known how virus influences the pathogenesis of those diseases. This article provides an overview of foreign scientific publications on parvovirus B19 structure, epidemiology, immune response and detection methods.

Correspondence to: mi2nac@gmail.com

Gauta 2014-03-13 